\title{
THE EFFECT OF STUDENTS' PERSONALITY LEARNING STYLE AND TEACHING METHODS ON THEIR VOCABULARY ACHIEVEMENT
}

\author{
Nurhafni Siregar \\ English Department \\ STKIP “Tapanuli Selatan” Padangsidimpuan, Indonesia \\ afniesiregar@gmail.com
}

\begin{abstract}
The objectives of the study are to investigate whether the students' personality learning styles affect the students' vocabulary achievement, to find out whether word walls significantly affects the students' vocabulary achievement and to find out whether there is any significant interaction between students' personality learning style and word walls on students' vocabulary achievement. An experimental research with factorial design $2 x 2$ was used in this research. There were 120 students from the fifth and sixth grade students of SDIT Bunayya Padangsidimpuan taken as sample of this research. Students' vocabulary achievement was measured by using test of multiple choice. The data were analyzed by applying Two-way Anova. The result of testing of the first hypothesis shows that students' vocabulary achievement that was taught by word walls is significantly higher than that was taught without word walls. The second hypothesis testing shows that students' vocabulary achievement with extrovert personality learning style higher than that have introvert personality learning style. The third hypothesis testing shows that there is an interaction between word walls and personality learning style. Students' vocabulary achievement is influenced by teaching method of word walls and personality learning style.
\end{abstract}

Key words: Extrovert, Introvert, Personality learning style, Word walls

\section{INTRODUCTION}

The purpose of education is one of the main components of the educational system.

With the goal of education, the education process is expected to be able to achieve results effectively and efficiently. English is a global language that should be mastered by the student in Indonesia because almost all of the countries in the world use English as the language to communicate each other. English hold the main important point in culture, education, and so on.

For that implication, there is English as the subject in every school. Especially in Indonesia, English learns as the foreign language. It means that Indonesian students should give more attention for English which is started from primary schools up to high school. 
People realize that teaching English at these levels become very important and need much concern.

Vocabulary is an important role in communication in reading forms. It can be concluded that if students have limited oral vocabulary, they will have difficulty to read the text due to the limited words understood by them. In order to achieve those goals, students must be able to master the vocabulary because it is one of or a part of language components.

For example, students who studied in SDIT Bunnayya Padangsidimpuan are still weak in English class mainly in vocabulary. This is seen in the average value of students, especially sudents of the fifth and sixth grade students of SDIT Bunnayya Padangsidimpuan. Their score of English test in vocabulary achievement administered by the researcher at the pre-test before is on the average 65. Meanwhile, the Criteria of Minimum Learning Mastery are 75 (KKM of the Fifth and sixth grade students of SDIT Bunnayya Padangsidimpuan). This suggests that students in fifth and sixth grade students of SDIT Bunnayya Padangsidimpuan still have lack vocabulary achievement. From the explanation above, is very obvious that many factors affect the quality of students learning outcomes. If we do not solve these factors, the result of student learning will be still far from expectation.

There are some factors why vocabulary is difficult for students: 1) The students tend to forget the words that have already been taught because most of their teachers only give the list of new words of English with their meanings in the students' native 2) The use of new words is not given in any meaningful sentences 3) The students cannot pronounce the new words of English well, because it usually uses a symbol in pronunciation.

Of course these entire make the vocabulary learning become tedious for the students because many words need to be memorized one without any good technique. As a result, the students always feel frustrated every time they learn new English words. Therefore, school teachers are expected to find suitable ways of teaching that can help their students get interested in the lesson and finally they can use the new words in their daily life.

As an English teacher, he or she demands to explore effective technique, method, and approaches. The development of information and technology requires educators, especially language to increase their capabilities and competencies in teaching language in 
the classroom. Many ways can be done to achieves that objective, both by sharpening the soft and hard skill owned by the teachers.

From explanation, previously, the writer is interested doing a research about students' vocabulary achievement with different personality learning style which is divided into two types extroversion and introversion. In this case the writer focuses on the interaction between teaching methods and students' personality learning style because we need to treasure which teaching methods can support students with their typical personality learning style especially in teaching vocabulary for primary students. The researcher tries to give an alternative technique of teaching English vocabulary using word wall and sees the interaction between these two methods with the students personality learning style.

\section{Vocabulary Achievement}

Esa (2006: 4) says, "Vocabulary as an essential skill students need to improve reading achievement. Vocabulary, or word meaning, is one of the keys to comprehension". It means that as students build connections between known words and unknown words, to be improved because it is the total number of words which makes up a language. So, without vocabulary, there is no language can be built.

The essential of building vocabulary also stated by Johnson (2008: 93), "Word knowledge affects student's ability to comprehend what they read, which in turn helps them expand their knowledge base, which in turn facilities their vocabulary growth, which in turn enchances their ability to comprehend what they read". It means that vocabulary is words are useful in all skill in English, even in productive and receptive forms. It shows that vocabulary is the key to achieve all skills and it the basic unit in a language.

From the explanation previously, the writer concludes that vocabulary is a collection of words or phrases which are usually arranged in sequence and translated or defined. Vocabulary achievement is an important role in the four language skill and it has to be considered that vocabulary is one of the needed components of language. The vocabulary achievement is very important as the basis for the students to support their language skill achievement.

According to Thornbury (2002: 3-12) there are at least six types of vocabulary, they are noun, pronoun, verb, adjective, adverb, preposition, conjunction. Here the writer 
describes only some of the parts of speech such as noun, pronoun, verb, adjective and adverb.

\section{a) Noun}

According to Gelderen (2010: 13), “A noun generally indicates a person, place or thing (i.e. this is its meaning). For instance, chair, table, and book are nouns since they refer to things. However, if the distinction between a noun as person, place, or thing and a verb as an event or action were the only distinction, certain nouns such as action and destruction would be verbs, since they imply action".

From the explanation, previously, the writer concludes that noun is a word that can function as the main or only elements of subjects of verbs (ex. A dog just barked), or of objects of verbs or prepositions (ex. to send money from home), and that in English can take plural forms and possessive endings (ex. Three of his buddies want to borrow John's laptop). Nouns are often described as referring to persons, places, things, states, or qualities, and the word noun is itself often used as an attributive modifier.

b) Pronoun

Pronoun is a word that substitutes for a noun or noun phrase. It is a particular case of a pro-form. According to Wekker (2007: 44), "Pronouns have traditionally been defined as words that are used instead of a noun or a noun phrase. Unfortunately this definition does not apply to all members of this word class. While it holds good for the third person personal pronouns in English (he, she, it and they), there are other pronouns that do not fit the definition (e.g. I and you)". It means that a pronoun is used in place of a noun or nouns. Common pronouns include he, her, him, I, it, me, she, them, they, us, and we.

In grammar, a pronoun is defined as a word or phrase that may be substituted for a noun or noun phrase, which once replaced, is known as the pronoun's antecedent. In a nutshell, it's because pronouns can do everything that nouns can do. A pronoun can act as a subject, direct object, indirect object, object of the preposition, and more.

c) Verb

A verb is a word that in syntax conveys an action (bring, read, walk, run, learn), an occurrence (happen, become), or a state of being (be, exist, stand). In the usual description of English, the basic form, with or without the particle to, is the infinitive. In many languages, verbs are inflected (modified in form) to encode tense, aspect, mood, and voice. A verb may also agree with the person, gender, and/or number of some of its arguments, 
such as its subject, or object. Verbs have tenses: present, to indicate that an action is being carried out; past, to indicate that an action has been done; future, to indicate that an action will be done.

Huddleston et al. (2005: 29) says, "Verbs are variable lexemes. That is, they have a number of different inflectional forms that are required or permitted in various grammatical contexts".

Based on previous explanation, researcher concludes that verb is a word that function as the main elements of predicates, that typically express action, state, or a relation between two things, and that may be inflected for tense, aspect, voice, mood, and to show agreement with their subject or object.

d) Adjective

Adjectives are words that describe or modify other words, making your writing and speaking much more specific, and a whole lot more interesting. Words like small, blue, and sharp are descriptive, and they are all examples of adjectives. Because adjectives are used to identify or quantify individual people and unique things, they are usually positioned before the noun or pronoun that they modify.

According to Huddleston et al. (2005: 112), “Adjectives typically denote properties of objects, persons, places, etc . : properties relating to age (old, young), size (big, small), shape (round, flat), weight (heavy, light), colour (black, blue), merit or quality (good, bad), and so on". It means that adjectives are words that describe or modify another person or thing in the sentence.

e) Adverb

An adverb is a word that modifies a verb, adjective, another adverb, determiner, noun phrase, clause, or sentence. According to Gelderen (2010: 16), "an adverbs modify adjectives or other adverbs, they are called degree adverbs (very, so, too).

Based on previous explanation, researcher concludes that an adverb is a word that is used to change or qualify the meaning of an adjective, a verb, a clause, another adverb, or any other type of word or phrase with the exception of determiners and adjectives that directly modify nouns. 


\section{Word Walls Media}

A word walls is a collection of words which are displayed in large visible letters on a wall, bulletin board, or other display surface in a classroom. The word wall is designed to be an interactive tool for students and contains an array of words that can be used during writing and reading.

According to Cronsberry (2004: 03), "word wall is a group of words that are displayed on a wall, bulletin board, chalkboard, or whiteboard in a classroom. The words are printed in a large font so that they are easily visible from all student seating areas. These words are referred to continually throughout a unit or term by the teacher and students during a variety of activities". It means that word wall is collection of vocabulary organized systematically displayed in large letters and placed on the walls of a classroom.

There are some more ideas that relate to how to can use the word wall in the classroom to teach new sight vocabulary, and how students can learn to use these words in context. According to Cronsberry (2004: 05) stated that there are ways to creating the word wall:

a. Mount the words on construction paper or card stock and laminate them.

b. Color code the words, either using colored markers for lettering or colored paper for mounting. Color coding can be used in numerous ways, e.g., same colors can be used to highlight homonyms, synonyms, parts of speech, frequently misspelled words, or categories.

c. Use a wall area that is visible to all students. If the word wall is to be used effectively, students need to be able to glance at the word wall from their desks while they are working.

d. Mount words on the wall in alphabetical order. Using alphabetical order makes it easier for students to skim the list and find words.

a. Make access to the words easy, e.g., use tape or tacks to mount the words so students can move individual words.

Based on the explanation above, the writer can be concluded that word wall media used to help facilitate learning in the classroom vocabularies. The medium used in the game is also quite simple, namely card and board letters to paste words that will be formed later. Students are required to compose letters that are still so random that will form a proper and meaning full words in accordance with a specific theme. 


\section{Personality Learning Style}

People learn in different ways. Just as we prefer different hair styles, clothing styles, managerial styles, and music styles, we also feel much more natural and comfortable acquiring information in ways that fit our preferred styles of learning. Learning style is defined as "any individual's preferred ways of going about learning" (Nunan, 2002: 168). Researchers in educational psychology as well as in second language acquisition (SLA) field have observed that learners tend to approach learning in a significantly different ways, and these ways are often referred to as "learning Style".

Personality type is a construct based on the work of Carl Yung. There are many personality types which have been identified; this section, however, just focuses on three major personality types significant in foreign language learning. They include extroversion/introversion and tolerance of ambiguity.

Extraversion/introversion is often thought of as being bipolar, but in reality it occurs along a continuum. People who fall at the extremes have clear preferences. Those who fall in the middle are called "ambiverts" and can function well in many different situations. Extroverts gain their greatest energy from the external world. They are energized by being with other people. They want interaction with people and have many friendships. Commonly, extroverts talk more and tend to take action with less reflection; they work better in groups than alone; they are good at interpreting body language \& facial expressions; they excel during classes with high levels of activity; they respond well to praise and competition; they take a lot of benefits from video-conferencing, face-to-face interaction, class discussion, multimedia, chat rooms, and group work. (Ehrman, 1999; Oxford, 2002)

Introverts derive their energy from the internal world, seeking privacy and tending to have just a few friendships, which are often very deep. They are energized by their own minds and find their energy levels rapidly reduced when interacting with others. Commonly, introverts talk less and reflect more before acting; like to be quiet; better at reflective problem solving and tasks involving long-term memory; like to work independently or with one or two other people; prefer slower, more accurate approach; may have trouble establishing rapport with others; oriented toward inner world of ideas and feelings; prefer low sensory input and low levels of activity; excel at focusing attention for long periods of time in situations if there are no distractions; and have a lot going on in 
their inner world. They take benefits from activities such as individual work and reading and writing assignments. (Ehrman, 1999; Oxford, 2002).

\section{METHODOLOGY}

This study was carried out by applying quantitative approach with an experimental design by using Factorial Design $2 \times 2$. There are three variables in this study, they are: independent variables: word walls method, moderator variables: extroversion and introversion personality learning style, and dependent variable: Students' vocabulary achievement.

There are 2 (two) groups of students in this research namely group that will be taught by using word walls and the group that will be taught conventinally.

The research was conducted in SDIT Bunayya Padangsidimpuan. The population of this research is the students in the 2016/2017 academic year. For authenticity purposes, the study is administered to a large number of population in four classes of them. Each class consists of more than 30 students so the total number of the students is more than 120 students.

There are 120 students that will become the sample. The writer randomly will select 60 students from extroversion personality learning style and assign 30 students to be given word walls method and 30 students to be given context clues.

An instrument is very useful in research because the instrument is used as facilitation in the research. In this research, there are two kinds of data; they are students' personality learning style which is measured by using questionnaire and vocabulary achievement test.

\section{RESULT}

\section{The students' vocabulary achievement that has taught by using word walls is} higher than that taught by conventionally.

Based on the result of data analysis shown that the students' vocabulary achievement that taught by using word walls got average $=28.87$ and students' vocabulary achievement that taught by conventionally got verage score $=25.17$. the result indicated $\mathrm{F}_{\text {observed }}=6.38>\mathrm{F}_{\text {table }}=3.92$. It means that null hypothesis has been rejected and it can be concluded that the first hypothesis of this research which stated that the the students' 
vocabulary achievement that has taught by using word walls is higher than that taught by conventionally was true.

\section{Students' Vocabulary Achievement that has extrovert learning style is higher than that have introvert learning style \\ Based on the result of data analysis shown that the students' vocabulary achievement} that have extroversion got average $=78.50$ and students' vocabulary achievement that have introversion got verage score $=40.83$. the result indicated $F_{\text {observed }}=14.1>F_{\text {table }}=$ 3.92. It means that null hypothesis has been rejected and it can be concluded that the second hypothesis of this research which stated that the the students' vocabulary achievement that have extroversion is higher than that have introversion was true.

\section{Interaction between word walls and learning style on students' vocabulary achievement}

The summary of ANOVA calculation indicated that $\mathrm{F}_{\text {observed }}=6.27>\mathrm{F}_{\text {table }}=3.92$.

It means that null hypothesis has been rejected and it can be concluded that the third hypothesis of this research which stated that there was a significant interaction between teaching method of word walls and personality learning style on students' vocabulary achievement.

\section{DISCUSSION}

\section{Word walls significantly Affect the Students' Vocabulary achievement.}

The findings of the study show that the word walls significantly affect students' vocabulary achievement. The total mean shows that students taught by using word walls have higher achievement in vocabulary achievement than students taught conventionally. This is because in word walls, the students should be active and more constructive. Another factor which might have led to this finding is the fact that the word walls activate the students motivation to fulfill the tasks in combining and constructing the vocabulary.

\section{Personality Learning Style Significantly Affect Students' Vocabulary Achievement}

The second finding of the study shows that personality learning style significantly affect students' vocabulary achievement. The total mean indicates that the students with extroversion have higher vocabulary achievement than students with extroversion. It means that students should possess extroversion because it will make them active and fully involved to construct the vocabulary. As what has been elobarated on chapter one, students' achievement in learning affect by two broad factors; internal and external factor. 
Personality learning style is one of internal factors which may affect students' achievement in their education. It is strongly prooved that personality learning style affect students achievement. Conscientiousness is related to students' academic achievement and has been linked to educational achievement and particularly to the will to achieve (Howard \& Howard, 1998). In this case, vocabulary achievement is a part of academic achievement, therefore, the students' achievement in vocabulary achievement will be higher if the students have extroversion.

\section{There is an Interaction between Pre-GO and Post-GO and Conscientiousness on Students' Achievement in Vocabulary achievement.}

The final finding of this study found out that there is a significant difference on the interaction between word walls and conscientiousness on students' vocabulary achievement. Students with extroversion that are taught by word walls have higher achievement in vocabulary achievement than students with introversion that taught the same instruction. It means there is an interaction between word walls and personality learning style.

Based on the above discussion, it can be concluded that personality learning style and word walls method affect students' vocabulary achievement. Students with extroversion are more motivated and constructive in building the knowledge into word walls. Above of all, to be success in education, the students should possess a good motivation and supported by other external factor such as effective teaching and learning strategies, and so on.

\section{REFERENCES}

Allen, Jannet. 2006. Words, words, words. USA: Stenhouse Publisher

Bungin, Burhan. 2005. Metodologi Penelitian Kuantitatif; Komunikasi, Ekonomi, dan Kebijakan Publik serta Ilmu-ilmu Sosial lainnya (edisi kedua). Jakarta: Kencana

ESA Regions. 2006. On Target: Strategies to Build Student Vocabularies. Rapid: Black Hills Special Services Cooperative (BHSSC)

Fathoni, Abdurrahmat. 2006. Metodology Penelitian \& Teknik Penyusunan Skripsi. Jakarta: Rineka Cipta

Jhonson. 2008. Teaching Reading and Writing. United Stated of America: Rowman \& Littlefield Publisher 
McCarten, Jeanne. 2007. Teaching Vocabulary Lessons from the Corpus, Lessons for the Classroom. United States of America: Cambridge University Press

Mukoroli, Joseph. 2010. Effective Vocabulary Teaching Strategies for the English for Academic Purposes Esl Classroom. SIT Graduate Institute

Selvia, Dewi. 2004. Improving Students' Vocabulary Mastery Using Contextual Teaching and Learning (A Classroom Action Research at the Third Grade of SD Negeri Kalimacan in Academic Year 2004/ 2005). Surakarta: Universitas Sebelas Maret

Thornbury, Scott. 2002. How to teach vocabulary. Charlbury: Bluestone Press 